\title{
The 2013 Immigration Reform that Wasn't
}

\author{
Alan LeBaron* \\ ELAINE LEVINE**
}

Possibly at no other time during the Obama administration, up to now, did it seem more likely that some type of immigration reform might be passed by Congress than in the early months of 2013. On January 28, a bipartisan group of four Democratic and four Republican senators, labeled by the media as "the Gang of Eight," publically presented their blueprint of a proposal for immigration reform. The next day during a speech in Las Vegas, President Obama spoke, once again, of the need to overhaul the nation's immigration system and mentioned goals similar to those announced by the eight senators. Two weeks later in his State of the Union Address he also insisted that it was time to pass comprehensive immigration reform. On June 27, 2013, the Senate passed the Border Security, Economic Opportunity, and Immigration Modernization Act (S744). Subsequently, five separate bills, each dealing with a specific aspect of immigration policy, were marked up in the House Judiciary and Homeland Security Committees but were never brought to the House floor for a vote. Thus, as 2013 draws to a close immigration reform has once again stalled in Congress.

Many different issues are addressed in the hundreds of pages of proposed legislation. Immigrants come to the U.S. from almost all regions of the world, bringing with them a wide range of educational backgrounds, class structures, languages, and ethnicities, and thus are often classified accordingly. There is a notable division perceived between low-skilled, less educated workers and high-skilled, highly educated professionals. As of the most recent census (USDOC, 2012), over half (53 percent) of the immigrants currently in the U.S. were born in Latin America, almost half of them (29 percent of the total immigrant population) are from Mexico, and many are from Central America, while Asians make up 28 percent of the foreign-born population, and Europeans, 12 percent. Perhaps the most salient division among immigrants today, certainly in the public eye, would be the bifurcation between those

\footnotetext{
* Professor of history and interdisciplinary studies at Kennesaw State University, alebaron@kennesaw.edu.

** Professor and researcher at CISAN, UNAM, elaine@unam.mx.
} 
who do have and those who do not have "legal" authorization to reside in the U.S. Hence, one of the most controversial aspects of almost any and all proposals for reform is how to deal with the estimated 11 million or more unauthorized immigrants. Therefore, in this introductory essay, we mainly focus our attention upon the unskilled and the undocumented Latino population, ${ }^{1}$ i.e., the people who make up the majority of the immigrants who face the greatest hardships and insecurity.

Attracting immigrant labor to the United States has been vital to economic growth throughout the nation's history, and migratory flows have generally more or less responded to changes in the demand for foreign labor. Over the past two decades, Latin American immigrants, in particular, have been an important component of labor force growth in the U.S. Latinos in general were responsible for 54 percent of the increase in the labor force between 2000 and 2010 (Kochhar, 2012), and in 2010 slightly more than half of the Latinos in the labor force (51.1 percent) were immigrants (Motel, 2012). In the latter part of the twentieth century the demand for lowskilled labor to carry out undesirable tasks (in low-skilled services, construction, food processing, and light manufacturing) for low wages rose considerably just as new waves of immigrants from Mexico and other Latin American countries arrived who were more than willing to fill such jobs.

Most recent European and Asian immigrants have high income levels commensurate with their high levels of educational attainment, which in many cases surpass those of the native-born population. Many Asians tend to be concentrated in highly specialized technical and professional areas. Furthermore, the number of unauthorized immigrants from European or Asian countries is quite low. In contrast, the high numbers of unauthorized workers from Mexico and their generally low levels of educational attainment, characteristic of most recent Mexican and Central American immigrants, make them extremely vulnerable in terms of working conditions and salary levels. Salaries deemed insufficient by most native-born workers are enough to attract immigrants from Mexico and Central America as long as there is a demand for their labor.

Mexico has long supplied the largest number of workers from south of the U.S. border. Over the past few decades, the demand for labor in the U.S. and the labor supply from Mexico and increasingly from Central America evolved in such a way that Latino immigrants became the primary source of low-skilled, low-wage workers in several branches of the economy and in various parts of the country. Low-skilled, unauthorized Latino workers have become an ideal source of "disposable labor"

\footnotetext{
1 "Latino" has complex usage, and does not appear ideal to describe all immigrants from Latin America, for example, the indigenous. We employ the word here only as a geographical generalization.
} 
that is available "just in time." They have proven to be readily available and easily expendable. They can be easily attracted or recruited in boom times and are totally expendable when the economy contracts. They can be laid off and even deported with no obligation from, or disadvantage for, their employers.

The severe 2008-2009 recession momentarily stemmed the arrival of new labor migrants, especially the unauthorized. The supply from Mexico and Central America is more or less adaptable -or can be forced to adjust- to demand conditions north of the border. From 2009 through 2013, given the severity of the recession and a climate of growing hostility toward immigrants, in some parts of the U.S., ICE removed an average of 1000 unauthorized immigrants a day, most of whom were Mexicans or Central Americans. The continued presence of large numbers of unauthorized immigrants, who have been actively recruited and/or readily employed by U.S. businesses and households, and the separation of families and other abuses and hardships suffered by those deported clearly evidence the urgent need for immigration reform in the U.S.

Even though new life was breathed into the immigration debate after the 2012 elections, the extreme partisan divisions that have plagued Obama's entire presidency prevailed once again and finally thwarted the possibility of achieving immigration reform in 2013. Moreover, lack of action at the federal level has prompted many states to take matters into their own hands. In most cases, states have invoked the argument of federal inaction as a justification for passing their own highly punitive laws to detect and remove unauthorized immigrants. However, there are some recent examples of states and localities that have enacted laws and implemented policies to allow immigrants some measure of rights and protections. We will return to this issue after first analyzing how, in addition to the adverse political context, unfavorable macroeconomic conditions prevailing during and after the recession through to the end of 2013 seem to have gotten in the way and kept the process from moving forward successfully.

\section{Great Expectations for Immigration Reform in 2013}

The demand for immigration reform has resounded in the halls of the United States Congress and across the nation since the beginning of this century. Although various proposals have been presented and voted on over the past 13 years, none has been approved by both houses thus far. President Obama was unable to fulfill his campaign promise to achieve immigration reform during his first term in office. Even the DREAM Act (Development, Relief and Education of Alien Minors Act) has succumbed to 
legislative impasse more than once since it was first proposed in the Senate in 2001. In what many have considered as a more or less desperate move to have at least something to offer to Latino voters in November, Obama implemented the Deferred Action for Childhood Arrivals (DACA) program on June 15, 2012. The U.S. Citizenship and Immigration Services offices began receiving applications for this program on August 15, 2012.

The fact that Obama received 71 percent of the Latino vote in the 2012 elections, as opposed to only 27 percent for Romney, seems to have made an impression on some Republicans with an eye to the future importance of Latino voters. This was the highest percentage of Latino votes for the Democrats since Bill Clinton received 72 percent in the 1996 election. In 2004, George W. Bush received 40 percent of the Latino vote (compared to 58 percent for Kerry), which is the highest percentage achieved by a Republican presidential candidate from 1980 to the present. In 2012, Latinos made up approximately 10 percent of the total electorate, up from 8 percent in 2004 (Pew Hispanic Center, 2012).

By the end of January 2013, Washington was buzzing with talk of immigration reform. In an opinion piece published in the Huffington Post on February 5, 2013, Darrell M. West of Brookings summed up the situation as follows:

Last fall, it would have been hard to imagine Republicans and Democrats working together to fix our broken immigration system.... But now we have leading Democrats and Republicans who have announced their support of a bipartisan reform package. With the Senate moving toward action, House Republicans indicating we should be open to immigrants, and President Barack Obama making immigration reform a top priority, the country appears close to taking meaningful action on this important issue. (West, 2013)

Among the reasons West cited for this dramatic change are Romney's poor performance in the 2012 elections, "the major driving force behind the changing dynamics of immigration reform"; the fact that "immigrants have moved into the heartland and out to the suburbs," which changes the local electoral landscape in many of these areas; the fact that in the future Republicans may face difficulties winning presidential elections due to changing demographics; the decline in the numbers of persons attempting to cross the U.S.-Mexico border illegally, which in his opinion "shows how the country has made progress on securing its border with Mexico"; and the recent "calls for action on immigration from leading companies being hurt by difficulty recruiting workers" (West, 2013). This is the case for high-tech areas where companies sometimes have difficulties in hiring qualified immigrants under the current rules, as well as for low-paying jobs in "agriculture, hotels, restaurants, and health care," 
where "there are insufficient numbers of [U.S.] Americans willing to work in these areas" (West, 2013). He concluded that "Meaningful immigration reform is vital to the long-term economy and national competitiveness" (West, 2013).

Economists share a more or less generalized consensus that immigration contributes positively to economic growth (Borjas, 2013). Numerous studies show how income earned by immigrant workers is quickly re-injected into the economy as consumer spending, thus generating a multiplier effect. For example, the Americas Society/Council for the Americas website, http:/ / www.as-coa.org, provides data on the positive contributions immigrants make to the economy via the housing market and as necessary workers in manufacturing, health care, and agriculture. Immigrants are directly involved in revitalizing many semi-rural or remote suburban areas throughout the country. Other economic studies refer to downward pressures on the wage level, particularly for workers with lower levels of educational attainment (Borjas, 2013). It should be pointed out that this pressure on wages could be alleviated significantly by regularizing the status of immigrant workers who are currently unauthorized.

Who benefits most or which groups of the population may suffer negative effects from the influx of immigrant workers are highly contentious issues. It is probably fair to say that the public in general does not closely follow the facts and figures, nor the complicated subtleties of the economic logic behind most of these discussions, even though many have very fixed ideas about immigrants and the immigration policies they favor or not. In times of crisis or what are perceived as threatening situations, people often try to find someone to blame for the adversities they face. Furthermore, as Manuel Castells has argued, in reference to a different political context, "People tend to believe what they want to believe. . . They filter information to adapt it to their preconceived ideas. They are much more reticent to accept facts that contradict their beliefs than those which coincide with them" (Castells, 2009: 229-230). That is why we are arguing here that the overall economic climate in the aftermath of the "great recession" is not one thus far that propitiates positive attitudes toward immigration reform.

By the end of 2013, the nationwide economy was looking somewhat better, and offering a bit more hope, but the recovery has been slow and uneven. The recession that began in December 2007 and officially ended in June 2009 was the most severe that the United States economy has experienced since the 1930s. The post-recession recovery has been exceptionally weak and unemployment remains unusually high. Real GDP did not surpass the pre-recession level until 2011. Up until then, and even beyond that point, there have been considerable fears that GDP growth could experience a second significant dip. The Bureau of Labor Statistics (BLS) recognized that 
"the employment decline experienced during the December 2007-June 2009 recession was greater than that of any recession of recent decades," and 47 months after the start of this recession, i.e., in November 2011, "employment was still over 4 percent lower than when the recession began" (USDOL, 2012a). In February 2012, the BLS pointed out that "many of the statistics that describe the U.S. economy have yet to return to their pre-recession values" and that the proportion of long term unemployed (those unemployed for 27 weeks or longer) remained notably high (USDOL, 2012a).

As of July 2012, three years after the recession had officially ended, the unemployment rate stood at 8.3 percent. There were 12.8 million people unemployed and 40.7 percent of these, or 5.2 million, were long-term unemployed. Also, 8.2 million persons involuntarily worked part time because they had failed to secure full-time work. Another 2.5 million were considered to be only marginally attached to the labor force because, although they were available for work and wanted to work, and had looked for a job sometime in the previous 12 months, they had not looked for a job in the 4 weeks prior to being surveyed. Over one-third (34 percent or 852 000) of those counted as marginally attached to the labor force were listed as discouraged workers, persons not actively looking for work because they believe no jobs are available for them. In other words, three years after the recession had ended 23.5 million people, 15 percent of the labor force, were either unemployed or underemployed (USDOL, 2012b).

By November 2013, the situation had improved somewhat but still disappointed expectations. The unemployment rate was 7.0 percent; 10.9 million people were unemployed, and 37.3 percent of these, or 4.1 million, were long-term unemployed. Because they have not been able to find full-time work, 7.7 million involuntarily worked part time. Another 2.1 million were considered to be only marginally attached to the labor force, as defined above. Over one-third (36 percent or 762000 ) of those counted as marginally attached to the labor force were listed as discouraged workers. In other words, almost four and a half years after the recession had ended, 20.7 million people, 13.3 percent of the labor force, were still either unemployed or underemployed (USDOL, 2013b).

Furthermore, since the recession began the labor-force participation rate has declined from an annual average of 66.0 percent in 2007 to 63.0 percent in November 2013. The number of persons 16 years old and over who were counted as not in the labor force rose from an annual average of 78.7 million in 2007 to 91.3 million in November 2013 (USDOL, 2013a, 2013b). The total number of persons employed, which was slightly fewer than 144.4, million, has not yet returned to its pre-recession level of over 146 million. The unemployment rate is 2.6 percent higher than it was before the recession began and would be significantly higher if the participation rate had not fallen to the lowest level registered in the past 35 years. 


\section{The ReCESSiOn's Impact on Latino Immigrants}

Before the 2008-2009 recession, Mexican and other Latin American immigrants easily found work in several labor market niches where their participation had grown rapidly during the 1990s and the first part of the 2000s: construction, meat packing, poultry processing, crop production, various branches of food processing, plant nurseries and landscaping services, building cleaning and maintenance, and personal care for children or the elderly, among others. The recession brought high levels of unemployment for all. Throughout the economic decline, from the beginning of 2008 until the middle of 2009 and the weak recovery thereafter, unemployment for Latinos, especially Latino immigrants, was consistently higher than the rate for non-Hispanic whites and lower than the rate for blacks, just as it has been since the 1970s or earlier.

After the first year of economic contraction, from the fourth quarter of 2007 to the fourth quarter of 2008, Rakesh Kochhar observed that labor market "outcomes for foreign-born Hispanics were the worst by both key indicators of employment -the percentage change in the number employed and the change in the employment rate" (2009: 4). In contrast, during the first year of recovery, officially beginning in July 2009, "foreign-born workers gained 656000 jobs while native-born workers lost 1.2 million" (Kochhar, Espinoza, and Hinze-Pifer, 2010: 3).

In attempting to explain these differences in employment patterns during the recession and in the initial stages of the recovery Kochhar, Espinoza, and Hinze-Pifer recognize that the reasons behind the observed behavior are not completely clear. They mention various factors that are most likely interacting to produce such results. First of all, "Research suggests that immigrants are more mobile than native-born workers, moving more fluidly across regions, industries, and occupations" (Orrenius and Zavodny [2009] and Borjas [2001], cited in Kochhar, Espinoza, and Hinze-Pifer, 2010: 3). In other words, immigrants tend to be more flexible in terms of when and where they work. Another reason might be simply that immigrants' employment patterns "are more volatile over the business cycle" ... registering "sharper losses in the early stages of recessions, but" rebounding "quicker in the recovery" (Kochhar, Espinoza, and Hinze-Pifer, 2010:3).

They also mention demographic changes as possible determinants of employment patterns. In the short run, "the ebb and flow of immigration is sensitive to the business cycle, with economic expansions tending to boost inflows" (Kochhar, Espinoza, and Hinze-Pifer, 2010: 3). In September 2010, Passel and Cohn estimated that "coincidental with the economic downturn, the number of unauthorized immigrants in the U.S. labor force fell from 8.4 million in March 2007 to 7.8 million in March 2009" (cited in Kochhar, Espinoza, and Hinze-Pifer, 2010: 3). By the third quarter of 2010, it 
seemed that the incipient economic recovery was "attracting immigrant workers back into the U.S." (Kochhar, Espinoza, and Hinze-Pifer, 2010: 3), and therefore into the labor force.

Moreover, "longer-term demographic trends might also be reasserting themselves during the recovery. The immigrant share of the U.S. labor force has been on the rise for several decades, especially since 1990" (Kochhar, Espinoza, and Hinze-Pifer, 2010: 3). Over the past two decades the foreign born component of the labor force has grown faster that the native-born labor force and "immigrant employment has tended to rise faster than native-born employment" (Kochhar, Espinoza, and HinzePifer, 2010: 3). Immigrants represented 16.6 percent of the employed civilian labor force in 2011, compared to 9.2 percent in 1990 (Migration Policy Institute, n.d.). Behavior at the beginning of the recovery has been consistent with the longer-run trend: "from the second quarter of 2009 to the second quarter of 2010, the number of immigrants in the labor force increased by 566 000" (Kochhar, Espinoza and Hinze-Pifer, 2010:3-4), while at the same time the number of native-born persons participating in the labor force actually declined by 633000 .

Furthermore, Kochhar, Espinoza and Hinze-Pifer (2010) confirmed that during the first year of economic recovery, starting in July 2009, the unemployment rate for immigrants began to fall slightly (a decline of 0.6 percent) even though unemployment for native-born workers continued to rise (by 0.5 percent). In spite of this employment growth, the total number of immigrants with jobs in mid-2010 remained below the pre-recession level. This was also the case among Latinos. The unemployment rate for Latino immigrants decreased slightly, from 11.0 percent in the second quarter of 2009 to 10.1 percent in the second quarter of 2010; meanwhile the rate for U.S.-born Latinos continued to rise, from 12.9 percent to 14.0 percent. Thus as the economy began to turn around and growth resumed, it seems that most of the initial gains in employment were for foreign-born rather than U.S.-born Latinos.

However, this small hike in immigrant employment was accompanied by a 4.5-percent decline in their earnings, whereas earnings for the native-born population fell by only 1 percent. Furthermore, Latino immigrants suffered the greatest wage losses. Their median weekly earnings decreased 1.3 percent from 2008 to mid-2009 and an additional 5.8 percent by the second quarter of 2010. As Kochhar, Espinoza and HinzePifer's study indicates, "Hispanics are the only group of workers whose median earnings decreased during both the recession and the recovery"; moreover, "the downward momentum in earnings for Latinos was led by immigrants." As a result of these changes, by the second quarter of 2010, the median weekly earnings of native-born workers stood at US\$653 and for foreign-born workers at US\$525. At the same time, the median for all Latinos was US $\$ 480$ and only US $\$ 422$ for Latino immigrants (2010: 20). 
Undoubtedly, Latino workers and Latino immigrant workers have directly suffered the effects of the most severe recession in the U.S. since the 1930s. They are among the millions who lost their jobs, or whose family members lost their jobs, and thereafter lost their homes because they could not meet the mortgage payments. Most of the U.S. citizens and legal permanent residents who became unemployed during this recession have received at least some relief from unemployment insurance payments, which are nevertheless surely insufficient to compensate for their losses. Obviously, none of the unemployed, undocumented immigrant workers have received any benefits whatsoever.

Furthermore, the repercussions, both direct and indirect, of this "great recession" for Latino immigrants in particular, and to some extent for Latinos in general, go far beyond the immediate economic impacts. The hard times experienced throughout the country have in some places, especially in some of the southeastern states, generated hostility toward those whom a few years earlier had been sought out and even actively recruited to fill thousands of jobs that local workers would not accept. It seems that various factors have combined to propitiate a hostile climate toward Latin American immigrants, in spite of the important role they have played in the country's economic dynamism in recent decades, up until the onset of the recession: 1) generalized anti-immigrant sentiments that flourished after September 11, 2001; 2 ) the growing numbers of immigrants, with greatly increased presence in new destinations; and 3) the severe recession, beginning at the end of 2007, with high and persistent unemployment rates since then.

In several states in the Southeast, these factors interacted with vestiges of racism and intolerance present in the region to exacerbate anti-immigrant feelings and attitudes and facilitate the passing of hostile, punitive state laws that would criminalize undocumented immigrants if they are allowed to take effect. Therefore, it is likely -and also most unfortunate- that the social and political impacts of this deep and prolonged recession will be felt for a considerable time after economic growth has been restored because of the anti-immigrant sentiments that took root in some parts of the country and flourished in the midst of the recession. However, as mentioned earlier, some states and localities have moved in the opposite direction.

\section{Some Cities and States Are Forging Their Own Immigration Policies}

Failure to pass needed immigration legislation by Congress in Washington D.C., although the federal government has the constitutional and legal power to decide 
immigration policy, has created vacuum in which states and local governments have been enacting their own immigration laws. Most salient in the eyes of the public and press have been the punitive and draconian immigration laws passed, for example, in Arizona, Georgia, South Carolina, and Alabama. But recently, powerful examples of states and localities enacting laws and policies allowing immigrants some measure of rights and protections have emerged. Some places have enacted laws and policies openly encouraging new settlements of immigrants, often with the goal of combating economic and demographic problems such as industrial decline and population loss. When city populations drop, cities lose political power and federal money, and some politicians and citizens have discovered that immigrants might be the solution to some of these problems.

California has become the primary outstanding recent example for the states. During 2013, Governor Jerry Brown signed into state law multi-bill legislation that established comprehensive protections and legal rights for people without documentation. One of these new laws prohibits enforcement officials from detaining immigrants for ICE when arrested for minor and non-violent crimes. Another law will allow undocumented immigrants to obtain driver's licenses. In addition, immigration attorneys will not be allowed to charge money for services related to immigration law before Congress passes such laws.

Cities that have passed local immigration reform measures to encourage economic development include Baltimore, Chicago, Cleveland, Columbus, Indianapolis, St. Louis, Lansing, and Detroit. According to The Washington Post, Baltimore's mayor signed an order "prohibiting police and social agencies from asking anyone about immigration status"; additionally, she "told Latinos, in particular, that she is counting on them to help Baltimore gain 10000 families within a decade" (Morello and Lazo, 2012). On October 7 2013, The New York Times published an essay highlighting immigration reform policies in Dayton, Ohio, and, although the program was still in the beginning stages, the early results were positive (Preston, 2013a). City officials claimed that such policies were not designed to attract undocumented immigrants, but that law enforcement would not seek out for arrest law-abiding individuals without authorized status.

By the end of 2013, various states and cities had to some extent endeavored to pass legislation designed to protect immigrants against deportation or punishment and promote a healthy work force. On the other hand, other locations remained adamantly anti-immigration. Perhaps hope exists that the progressive states and cities will become examples of success that others will follow. In the past, states have enacted laws when the federal government has failed, sometimes becoming examples that other states and perhaps Washington eventually follow. Past examples where state 
policy has influenced national policy would include California's environmental laws and Massachusetts's health care laws. The new laws to tax and allow the sale of marijuana in Colorado may influence other states that are currently considering such laws. To be sure, local and regional differences and needs make it difficult for all states and cities to aspire to the same legislation. Economists and others should watch for the outcomes and consequences of laws already passed to see how effective these policies prove to be in promoting economic development and social stability.

The Southeast is a specific geographic region of the United States, well known for its history of a slavery-based economy, post-slavery black and white segregation, and contemporary Red state politics. The U.S. "South" includes Texas and Oklaho$\mathrm{ma}$, and sometimes the essays in this special edition speak of the South in general. The southern states passed some of the earliest and toughest laws on immigration. No doubt the South continues to be complicated by the vestiges of its past, but the degree to which the southern past relates to current southern reaction to Latino immigration is difficult to establish. Does the South's historic racism influence southern feelings toward Latinos and immigrants? In her study of anti-immigrant feelings in Georgia, Elaine Levine (2012) found the evidence for old-style southern particularism mixed and inconclusive. The South, at least, appears less blatantly racist than during the decades before the 1970s. Moreover, pockets of nativism and racism exist throughout the United States. Regine Jackson notes, for example, that "unlike the South of old, this transformed zone holds no distinction as the bastion of racism in [U.S.] American life" (2011: 29). The South regionally, however, undeniably stands out for its rates of poverty, income inequality, and lackluster efforts to promote general prosperity for working-class citizens. It would appear unlikely that draconian statelevel immigration laws are helping to overcome the region's problems.

\section{Is a Path to Citizenship Necessary at This Point?}

While the federal government, state and local governments, and civil society nongovernmental actors variously struggle and compete for power and influence, many thousands of undocumented immigrants continue living precarious lives. As noted above, immigrants come from various education backgrounds, class structures, geographic regions, and ethnicities, but one salient divide can be drawn between those who do have and those who do not have documented authorization to reside in the United States. People without authorization -it should be safe to say in generalhold the possibility of eventual U.S. citizenship to be less important than gaining the security of jobs and monetary income to provide for their daily survival. However, 
advocating for eventual citizenship has been standard for most immigrant-rights groups, often under the logic that legalized but non-citizen workers would create permanent underprivileged groups that could be easily taken advantage of, which would be detrimental to the ideals of the United States.

In The New York Times, Julia Preston (2013b) reported that immigrants were divided on the importance of obtaining U.S. citizenship, but that for many of the undocumented more important were necessities such as driver's licenses and the fear of being deported. A Pew Research Center report released in December found that "while lopsided majorities of Hispanics and Asian Americans support creating a pathway to citizenship for unauthorized immigrants, two new surveys from the Pew Research Center also show that these groups believe it is more important for unauthorized immigrants to get relief from the threat of deportation" (Lopez, et al., 2013: 4). Indeed, when the undocumented are given a chance to speak, we find that far more profound a consideration than citizenship is the danger, indignity, hardship, and uncertainty faced each day.

Alan LeBaron's conversations with the undocumented would substantiate their preoccupation with daily survival, and not eventual citizenship. Inside the Maya Heritage Community at Kennesaw State University, he maintains close relations with Maya-indigenous from Guatemala, and the following four examples "of what they think" give some insight into the thinking of the most vulnerable of the undocumented. The first two examples are two men who were deported back to Guatemala several years ago. Before deportation, he had known them for approximately 10 years. The second two, brother and sister, continue to live without authorized papers in the United States, and Alan has known them for about five years. In meeting and discussing the issues of immigration with them, it became clear that what was most important to them was security from imprisonment and separation from families, and work. All four were relatively uninterested in the path to citizenship, which seemed far out of reach anyway.

He visited with Juan in Guatemala in August 2013. Sitting at a café in the colonial town of Antiqua, Alan told him that activist groups were working hard to bring about comprehensive immigration reform with a solid path to citizenship. Juan startled Alan when he proclaimed with bitterness, "We just want a job. Give us work." Juan had observed activists, he said, especially Latino activists who organized marches and encouraged or coerced immigrants without papers to join the protest crowds. In his opinion, such activities had often given the hard-working immigrant a bad image. He had once joined a protest trip to D.C. while he was working in the United States, and he said people taking part in the protest "behaved badly," for example, walking on the grass and flowers. Juan believed that such marches and group rallies had turned 
people against the immigrants, which helped bring about his deportation. "If people knew we just wanted work they would let us stay." Juan had worked for the same employer for most of the 10 years he stayed in the United States, and they communicated regularly by telephone. His ex-boss, Juan said, would drive to the border to pick him up if he came back, and also told Juan, "Whites won't work; they smoke, talk on the telephone, and they're slow." Juan agreed that citizenship might be nice, but what he really wanted was a chance to work.

Several days later Alan met with Nicolas, a married man, three of whose children were born U.S. citizens while he worked in the United States. Nicolas had found happiness in being re-united, after deportation, with relatives and friends, but he was constantly thinking of returning to the United States. He had applied for asylum in the second year of his migration, and while his case was pending, for over eight years, he provided well for his family. His major crisis during the eight years was the slow death of his mother from cancer, during the time that he could not depart from the United States without having his work permit revoked. Eventually, after he and his family were deported, he and his brother bought land and invested in calves and coffee. But the coffee land he had purchased had become diseased, and his calves had not yet matured enough to produce milk. He had depleted his savings from the United States before he could finish building his house. During the deportation proceedings the judge had warned him that if he returned without documents, he would lose the possibility of becoming a citizen after his children had grown. Nicolas's brother had recently tried reaching the United States and was apprehended and was currently in detention, and the family had lost the US\$5000 investment in the failed journey. Nonetheless, Nicolas was thinking strategically about the best way to return to the U.S. He told Alan, "There is no work in Guatemala, and I'm going to lose my land. If I can work [in the U.S.] for another few years, I can finish my house."

The other two examples are of a brother and sister who continue to live in the United States, although not with each other. The sister's husband left her, and she has two small children, both born in the United States. She shares an apartment with another family, and takes taxies every morning and evening from work. She has baby sitter expenses and makes less than minimum wage for the hours she works. But she wants to stay in the United States as long as possible, because life in Guatemala as a single woman would be far worse and less secure. The debates over the path to citizenship are not something she follows; understanding how to keep her children in school and how to apply for her children's benefits are already extremely complex. The brother's case illustrates the calculated risks taken by immigrants when they are desperate to stay in the United States. His daughter, born in the United States, has been recovering from cancer, and in order to find work that paid full and reliable 
wages, he purchased a fake identification and social security card, paying US $\$ 8000$. He understands that, if apprehended, he will spend time -possibly a lot of time- in jail. Citizenship, he said, is not as important as the ability to work without the danger of imprisonment and separation from his family.

We co-editors remain convinced that the U.S. economy and society would grow and prosper better if Washington D.C. established comprehensive reform to create a simple and viable path to citizenship, but if the fastest method of decriminalizing and giving daily security to the millions of undocumented would be legislation achieved through step-by-step, or piecemeal measures that may not include paths to citizenship in the short run, so be it. We are not advocating that undocumented workers be put into temporary worker programs, although we realize that temp programs might become a limited part of any comprehensive program. Indeed, we wrote in a previous special issue of Norteamérica, "temporary worker programs will produce their own basket of problems" (Levine and LeBaron, 2011: 20). Perhaps activists and academics should work more closely with the Republican leadership and the Republican business wing, where space for common ground appears to exist. Another strategy is taking what we can on the federal level and working to create more states like California and more cities like Dayton and Detroit.

But we should not leave this essay in deep gloom just yet. Positive conditions have been emerging as well, such as the improving economy in many areas and recent polls showing that the majority of U.S. Americans now accept some kind of path to citizenship. Previously, during the good economic times before the recession, passage of significant comprehensive reforms on the federal level seemed plausible. Perhaps after several years of slow recovery and widespread recognition that immigrants can help the economy further, the year 2014 might be a little better, hopefully for all, and maybe even for immigration reform.

\section{The Articles in This Special Issue of Norteamérica}

The articles that appear in this special issue of Norteamérica were first presented as papers at the $4^{\text {th }}$ Conference on Immigration to the Southeast, held in metropolitan Atlanta, Georgia, in October 2012. The conference promoted interdisciplinary approaches and considered the concept of "immigration studies" that included the interlacing studies of race, education, public policy, migration history, international relations, and human rights. Problem solving and conflict management were conference themes. Given the fact that no visible progress was made in 2013 toward overhauling the country's currently faulty immigration system, the ideas and analysis presented 
in these articles are just as valid and timely as they were a little over a year ago when the conference was held.

In her essay on "Institutional Racism in the Enforcement of Immigration Law," Doris Marie Provine posits that in the U.S., "race and immigration law are, perhaps inevitably, intertwined." While recognizing that "over time, the role of race and racism in immigration law has changed," she argues, nonetheless, that, despite the fact that "race-neutral rules" have apparently or supposedly "found favor" in recent years, the existing "mix of federal, state, and local law and policy ... institutionalizes racism by facilitating ethno-racial profiling, hyper-surveillance, abusive stops, problematic searches, and unwarranted detention of suspected unauthorized immigrants." Furthermore, Provine maintains that "the targets of these actions are disproportionately Latinos because U.S. Americans, including members of the law enforcement community, have been conditioned to see the problem of unauthorized entry and residence in racial terms, as a Mexican and Central American phenomenon."

After denouncing current federal deportation practices where, "despite an avowed policy of concentrating resources on serious criminal violators, the record is of escalating deportations made up mostly of residents with little or no involvement in crime," she turns her attention to the case of Arizona. She explains how "beginning in 2004, voters embraced a series of initiatives to eliminate rights that unauthorized residents had long enjoyed, including in-state tuition. . . . Around 2005, . . county Sheriff Joseph Arpaio began to undertake workplace raids and 'crime suppression sweeps' in predominantly Latino neighborhoods in the Phoenix metropolitan area." She provides several examples of how state laws, including of course SB1070, have been used to unjustifiably harass Latinos in Arizona. However, as she points out, in response, "Latino immigrants and their supporters are creating significant political pressure for changes," which may lead to some sort of immigration reform at the national level.

In her essay on "The Biopolitics of Asylum Law in Texas: The Case of Mexicans Fleeing Drug Violence in Juarez, Ariadna Estévez states that while labor migration from Mexico to the U.S. has noticeably declined over the past few years, the number of Mexicans seeking asylum there has grown considerably. She cites sources ascertaining that "two percent of the Mexican population (over 1.6 million people) has been forcibly displaced by criminal violence." Furthermore, she maintains that in the twin cities of the northern border region many individuals and families affected by the rise in drug related violence have sought refuge in the U.S., especially in Texas. As a result, "By 2010, Mexico was responsible for one of the highest numbers of asylum requests in the United States, second only to China." She also points out that "acceptance rates, on the other hand, are practically non-existent." 
The author applies Michel Foucault's concept of biopower as she "examines the role of asylum law" in controlling Mexican migration to the U.S. One of the main objectives is to "show how instruments intended for the administration of international justice, such as the Refugee Covenant included in the INA (Immigration and Nationality Act), are used for the regulation of immigration to the U.S." Estévez provides many examples to illustrate the ways in which "biopolitical tactics" are used to facilitate "migration control." More specifically she argues that extremely narrow interpretations of asylum law are frequently used "as a means of denying this option to people fleeing violence." The central conclusion is that "there is evidence suggesting that the U.S. American government is using asylum law biopolitically" in order "to prevent Mexicans from being granted asylum."

Mikhail Lyubansky, Paul A. Harris, William E. Baker, and Cameron D. Lippard, in their essay "'One Day on the Red Hills of Georgia': The Effects of Immigration Status on Latino Migrants' Experiences of Discrimination, Utilization of Public Services, and Attitudes toward Acculturation," compare documented and undocumented Latino immigrants "regarding their experience of discrimination, utilization of services, identity preferences, mental health, and beliefs in five domains: vulnerability, injustice, distrust, superiority, and helplessness." The authors provide solid background on immigration into Georgia and describe the public attitudes and political debates that influence and shape immigrants' lives. Despite the difficulties, immigrants remain vital to Georgia's economy, and "neither the lack of English fluency nor other obstacles to employment (e.g., documentation) seem to be keeping Spanish-speaking migrants in Georgia out of the work force." But the absence of documents creates real problems for immigrants, including treatment by the general public, blatant discrimination, and the stress and anxiety that come from the danger of arrest and deportation.

In order to examine the differences between documented and undocumented immigrant lives, the authors arranged interviews with 127 Spanish-speaking adults, 49 percent undocumented and 51 percent documented. To promote trust and accuracy, survey participants were recruited and the surveys administered by Catholic Charities social workers. Carefully constructed questions that included topics concerning identity, acculturation, discrimination, service utilization, and mental health demonstrated that in many respects documented and undocumented experiences, as might be expected, had significant differences. For example, undocumented respondents reported "significantly more personal helplessness and significantly less life satisfaction." But the authors found no significant differences between the two groups in terms of identity or acculturation variables, and that both kinds of immigrants had similar levels of aspirations to become assimilated and acculturated into 
U.S. society and culture. Given that immigrants appear in general good for the economy and that they want to assimilate, "lawmakers should feel confident that neither the U.S. economy nor the nation's social fabric would be harmed by amnesty."

In his article "Shaping Twenty-First-Century Civil Rights Advocacy: Latinos in Metro Atlanta," David A. Badillo "chronicles the Mexican American Legal Defense and Educational Fund's civil rights history in Atlanta and the Southeast from 2000 to 2009 and beyond." He maintains that "during the 1970s and 1980s, MALDEF had emerged on the national stage as a feared and powerful defender of Mexican-Americans, mounting vigorous litigation campaigns that enervated lingering de facto school segregation the Southwest and granted greater access to voting rights while challenging discriminatory redistricting schemes." In subsequent years, this organization "became the voice of non-citizens and non-Mexican Latinos as well." By the end of the twentieth century, it seemed evident that the time had come for MALDEF to consider "the possibility of expanding the reach of the organization into the Southeast."

"Of all the possible locations for a southeastern office, Atlanta turned out to be best." Ensuing events led MALDEF to shift their attention from desegregation and voting rights issues to defending the "civil rights of unauthorized immigrants." Badillo explains how "the first decade of the twenty-first century proved to be a trying time for MALDEF -nationally and for its Atlanta office- as a more restrictive civil rights climate emerged in the aftermath of September 11, 2001, which contributed to diminishing MALDEF's resources even as it enhanced the need for advocacy." Despite the organization's intentions and its desire for greater presence in the Southeast, a variety of events led to "the closing of the Atlanta regional office in April 2009." As the author's analysis shows, the current situation in the Southeast, as well as in other regions, requires more not less local presence and involvement from organizations like MALDEF.

Richard Vengroff, in his article "Immigration Policy at the Sub-National Level in North America: Quebec and Georgia in Comparative Perspective," compares Canadian and U.S. immigration policies, and in particular the Canadian province of Quebec and the U.S. state of Georgia. The differences are striking, and their comparisons should lead to deeper understandings of the problems and the efforts for solutions in both nations. Vengroff describes how Canadian provinces, and especially Quebec, have obtained significant participation in the recruitment, selection, and integration of new immigrants. In the United States, immigration policy remains overwhelmingly with the federal government, although the individual states have made strong efforts in the last decade to exert state authority, especially regarding undocumented immigration. Vengroff explains that although indices have been developed to measure and compare national-level immigration policies, the means to compare sub-national levels have been lacking. His article especially looks at the 
comparative success of integration and naturalization for new immigrants in Georgia and Quebec. Success is greater in Canada, where the governments have taken strong, positive steps to insure immigrants' integration, and much less so in the United States, where the federal government offers little help or publically funded integration services. Vengroff notes that "global competitiveness now dictates that in addition to sovereign countries," regional governments such as states, provinces, and cities must work to attract and retain the most creative talent.

One of the immigration variables examined by Vengroff is the status of having official documents or not having documents. Canada has done more to bring in and to integrate skilled laborers who already speak French or English than has the United States. Although "illegal" immigration is also problematic and controversial in Canada, "overall, public opinion in Canada remains generally quite favorable to immigration especially when compared to the U.S. and other western democracies." In the case of Georgia, Vengroff notes that when labor needs became severe, it was private business that recruited undocumented workers from south of the border and other U.S. states in the absence of either federal or state help with fulfilling those needs. Both regions are continually in flux and change, as political, economic, and demographic factors unfold, but apparently the United States could learn from some of the policies enacted in Canada and Quebec.

For her special contribution on "Teaching immigration: Informing and Elevating the debate," Margaret M. Commins conducted extensive surveys of university classes in the Southeast and found that relatively few courses included the study of immigration. Commins notes that "public discourse about immigrants and immigration reform is laden with negative terms and stereotypes," and university students are immersed in this discourse. However, results from the survey of 50 colleges and universities in the Southeast demonstrate that undergraduate courses dealing with immigration are rare, and the classes which are taught are "almost always done so from a particular disciplinary perspective." Thus, not only are more courses needed on immigration, but given the complexity and newness of the national immigration question, they should be interdisciplinary and based on problem solving, critical thinking, and community engagement. Well-designed courses on immigration might promote "a sense of social responsibility, strong intellectual and practical skills, and the ability to apply them in real-world settings."

Central to the Commins article is her argument that interdisciplinary and problem-based courses must be designed to effectively teach about the complexities of contemporary immigration, because research on immigration must be "fundamentally interdisciplinary" to include "history, politics, foreign policy, sociology, economics, law, and a range of other disciplines." She offers various perspectives and sugges- 
tions on how the difficulties and controversies associated with immigration research can be excellent teaching and learning opportunities and makes a special case for integrating service learning and undergraduate research and gives an example of her own experience in teaching immigration. Other examples of service learning and community engagement with immigration classes, taken from a conference roundtable organized by Commins, are also discussed.

In their special contribution "Research and Praxis on Challenging Anti-Immigration Discourses in School and Community Contexts," Martha Allexsaht-Snider, Cory A. Buxton, and Ruth Harman examine theoretical perspectives and give case examples in research and praxis that challenge anti-immigration discourse and practice in schools and communities. In 2012, the authors were co-editors of the special issue on immigration for the International Journal of Multicultural Education (IJME), and the eight research studies from that special IJME edition, along with a selection of classic and recent work on immigration and education, are discussed and compared in this essay. The authors first discuss critical discourse analysis (CDA) as applied to the issues of immigration, "where focus is placed on the analysis of inequitable power structures and transformative social change." CDA becomes the theoretical and methodological framework that can help educators and researchers challenge anti-immigration beliefs. "Our purpose," explain the authors, "is to provide readers with a working knowledge of how CDA might be applied in critical and transformative ways when challenging current immigration policies and practices." The authors explore several research studies using $\mathrm{CDA}$, one of which is a case example of an arts-based program conducted with a collaborative team of teachers and researchers who "over the course of a year and a half included the sequential use of performance, storytelling, collective voting and writing, as well as conference presentations."

In the second section of their article, Allexsaht-Snider, Buxton, and Harman discuss examples of critical race theory (CRT) as applied to critical thinking on race, identity, and power. As with CDA, CRT becomes an effective means to challenge anti-immigration concepts and develop new praxis. The authors explain that CRT acknowledges that race and racism is inherent in educational institutions and governmental policies, and teachers and students could use CRT to better understand the debates over immigration as well. In order to contend with these problems in race and power as applied to immigration, the authors review theories on culture and advocate for "resource pedagogies" that would recognize that "linguistic, cultural, and literacy tools that all students bring to the classroom can be used advantageously to develop the knowledge and skills that are most valued in academic settings." For example, the authors describe the "Language-Rich Inquiry Science with English Language Learners Project," which utilized resource pedagogy to "support equitable education for 
immigrant students." Overall, Allexsaht-Snider, Buxton, and Harman describe some strong activist approaches to academic research and teaching.

Thus, as 2013 draws to a close, the immigration question in the United States remains complex and unresolved, and comprehensive reform providing a path to citizenship for undocumented immigrants seems continually out of reach. No doubt the debate on immigration reform will continue in 2014. Therefore we invite you to consult the call for papers that appears at the end of this issue and to consider participating in the next conference which will be held at the University of Florida in October 2014.

\section{BIBLIOGRAPHY}

Americas Society, Council of the Americas

2013 http:/ / www.as-coa.org/, accessed December 6, 2013.

\section{BORJAS, GEORGE}

2013 "Immigration and the American Worker. A Review of the Academic Literature," Center for Immigration Studies, http: / / cis.org/sites/ cis.org/ files / borjas economics.pdf, accessed April 9, 2013.

2001 "Does Immigration Grease the Wheels of the Labor Market?" Brookings Papers on Economic Activity, no. 1, pp. 69-119.

Castells, Manuel

2009 Comunicación y poder, Madrid, Alianza Editorial.

JACKSON, REgINE O.

2011 "The Shifting Nature of Racism," in Cameron D. Lippard and Charles A. Gallagher, eds., Being Brown in Dixie: Race, Ethnicity, and Latino Immigration in the New South, Boulder, Colorado, First Forum Press, pp. 25-51.

KOCHHAR, RAKESH

2012 "Labor Force Growth Slows, Hispanic Share Grows," http:/ / www.pewso cialtrends.org/2012 / 02 / 13 / labor-force-growth-slows-hispanic-share -grows-2/, accessed February 13, 2012.

2009 “Unemployment Rises Sharply among Latino Immigrants in 2008," Washington, D.C., Pew Hispanic Center, February 12. 
KochHar, RaKesh, C. Soledad Espinoza, and Rebecca HinZe-Pifer

2010 "After the Great Recession: Foreign Born Gain Jobs; Native Born Lose Jobs," Pew Hispanic Center, Washington, D.C., October 29, http:/ / www.pewhis panic.org/2010/10/29/after-the-great-recession-brforeign-born-gain-jobs -native-born-lose-jobs.

LeVINE, Elaine

2012 "Sentimientos antiinmigrantes en el estado de Georgia," in Mónica Verea, ed., Anti-immigrant Sentiments, Actions, and Policies. The North American Region and the European Union / Sentimientos, acciones y politicas antiinmigrantes. América del Norte y la Unión Europea, Mexico City, CISAN-unam, pp. 175-189.

Levine, Elaine, and Alan LeBaron

2011 "Immigration Policy in the Southeastern United States: Potential for Internal Conflict," Norteamérica, year 6, special issue, pp. 5-31.

Lopez, Mark Hugo, Paul Taylor, Cary Funk, and Ana Gonzalez-Barrera

2013 “On Immigration Policy, Deportation Relief Seen as More Important than Citizenship: A Survey of Hispanics and Asian Americans," Washington, D.C., Pew Research Center, December 19, http: / / www.pewhispanic.org / files / 2013/12/hispanics-asians-immigration-legislation_12-2013.pdf.

\section{Migration Policy Institute}

n.d. Immigration Data Hub, “2011 American Community Survey and Census Data on the Foreign Born by State" Section The United States, Workforce characteristics, http:/ / www.migrationinformation.org/ datahub/ state3.cfm?ID=US\#1, accessed December 2013.

Morello, CAROL, and Luz Lazo

2012 "Baltimore Puts out Welcome Mat for Immigrants, Hoping to Stop Population Decline," The Washington Post, July 24, http:/ / www.washingtonpost. com/local / baltimore-puts-out-welcome-mat-for-immigrants-hoping-to -stop-population-decline/2012 / 07/24, accessed November 4, 2013.

Motel, SETH

2012 "Statistical Portrait of Hispanics in the United States, 2010," Washington, D.C., Pew Hispanic Center, http: / / www.pewhispanic.org/2012/02/21/ statistical -portrait-of-hispanics-in-the-united-states-2010/, accessed February 21, 2012. 
Orrenius, Pia M., and Madeline Zavodny

2009 "Tied to the Business Cycle: How Immigrants Fare in Good and Bad Economic Times," Migration Policy Institute, Washington, D.C., November.

Passel, Jefrerey S. and D’Vera Cohn

2010 "U.S. Unauthorized Immigration Flows Are Down Sharply since Mid-Decade," Pew Hispanic Center, Washington, D.C., September 1.

\section{Pew Hispanic Center}

2012 "Latino Voters in the 2012 Election," November 7, http:/ / www.pewhispan ic.org/files / 2012/11/2012_Latino_vote_exit_poll_analysis_final_11-07-12.pdf.

Preston, Julia

2013a "Ailing Cities Extend Hand to Immigrants," The New York Times, October 7, pp. A-1, A-17.

$2013 b$ "Illegal Immigrants Are Divided over Importance of Citizenship," The New York Times, November 21, pp. A-1, A-3.

usdoc (U.S. Department of Commerce, Census Bureau)

2012 "The Foreign-Born Population in the United States: 2010," American Community Survey Reports, May, http://www.census.gov/prod/2012pubs / acs-19.pdf.

usdol (U.S. Department of Labor, Bureau of Labor Statistics)

2013a "Labor Force Statistics from the Current Population Survey, Table 1. Employment Status of the Civilian Noninstitutional Population, 1942 to Date," last modified February 5, http:/ / www.bls.gov/cps/cpsaat01.htm, accessed December 6, 2013.

2013b "Economic News Release, The Employment Situation-November 2013," December 6, http:/ / www.bls.gov/news.release/empsit.nr0.htm, accessed December 6, 2013.

2012a "Spotlight on Statistics, The Recession of 2007-2009," February, http: / / www .bls.gov/spotlight/2012/ recession/.

2012b “News Release, The Employment Situation-July 2012," Friday, August 3, http:/ / www.bls.gov/news.release/archives/empsit_08032012.pdf.

2008 "Employment and Earnings," vol. 55, no. 1, http: / / www.bls.gov/opub / ee/ empearn200801.pdf, accessed July 9, 2013. 
West, DARrell M.

2013 "How the Politics of Immigration Reform Have Changed," The Huffington Post, February 5, http:/ / www.brookings.edu/research/opinions/2013/02/ 05-immigration-reform-west, accessed February 7, 2013. 